Martins, Ana Maria (2016). A colocação dos pronomes clíticos em sincronia e diacronia. In: Ana Maria Martins \& Ernestina Carrilho (eds.), Manual de Linguística Portuguesa. Berlin/Boston: De Gruyter. 401-430.

\title{
15 A colocação dos pronomes clíticos em sincronia e diacronia
}

\begin{abstract}
Neste capítulo descreve-se a colocação dos pronomes clíticos no português europeu contemporâneo, pondo em destaque as especificidades do português europeu no quadro das línguas românicas. Depois oferece-se uma perspetiva diacrónica que identifica os pontos de estabilidade e de mudança no sistema de colocação dos pronomes clíticos e mostra como, ao longo do tempo, o português divergiu sintaticamente de outras línguas ibéricas com as quais partilhava, no período medieval, um padrão idêntico de distribuição da próclise e da ênclise. Neste percurso de divergência, o português preserva aspetos centrais do sistema original, em contraste com línguas como o espanhol e o catalão. O capítulo aborda ainda a questão da interpolação (i.e. a descontinuidade entre clítico e verbo) e esclarece que a interpolação dialetal observável no português europeu contemporâneo não é a continuação da interpolação medieval. Ao longo do capítulo identificam-se questões em aberto relativamente ao tópico em análise.
\end{abstract}

Keywords: padrões de colocação dos pronomes clíticos, ênclise/próclise, interpolação, mudança sintática, variedades do português

\section{Introdução}

O padrão de colocação dos pronomes clíticos apresenta, no português europeu, especificidades que o afastam bastante dos padrões de colocação, mais simples, da maior parte das línguas românicas. Com o português europeu alinham apenas o galego (Álvarez/Xove 2002) e, parcialmente, o asturiano (González i Planas 2007; FernándezRubiera 2006; 2009; 2010). Numa perspetiva diacrónica, o português europeu mantém, no entanto, um sistema de colocação dos pronomes clíticos que, em aspetos essenciais, era partilhado com as outras línguas românicas medievais. A sua complexidade poderá estar na origem dos processos evolutivos, no sentido da simplificação, que virão a ocorrer no seio da família românica e que levarão à diversidade de padrões de colocação dos pronomes clíticos que hoje conhecemos. A complexidade do sistema de colocação dos pronomes clíticos está também na base da aquisição mais tardia deste aspeto da sintaxe pelas crianças portuguesas, comparativamente às crianças francesas, italianas ou espanholas (cf. Costa/Fiéis/Lobo 2014) e não é menos desafiante para quem aprende o português europeu como segunda língua (cf. Madeira/Xavier 2009).

No quadro românico, o português brasileiro falado tem o sistema mais simples, pois apresenta próclise generalizada, com o clítico a ocorrer sempre imediatamente antes do 
verbo de que é complemento, quer com as formas finitas quer com as formas não finitas do verbo, incluindo, além do infinitivo e do gerúndio, o particípio passado (cf. Kato/Martins 2016).

Português brasileiro

(1) a. O chefe me despediu.

próclise ao verbo finito

b. Me dá um beijo.

c. Você não pode me despedir.

próclise ao imperativo

d. Ele está sempre me provocando.

e. Você não tinha ainda me contado.

próclise ao infinitivo

próclise ao gerúndio

próclise ao particípio passado

O francês tem o sistema que mais se aproxima do português brasileiro, mas deixando fora da próclise generalizada o imperativo morfológico, com o qual os pronomes clíticos ocorrem imediatamente depois do verbo, ou seja, em ênclise. Além disso, o francês, como a maior parte das línguas românicas, não admite cliticização ao particípio passado.

Francês
(2) a. Je le rencontre chaque jour.
próclise ao verbo finito
b. J'ai tout fait pour te voir.
próclise ao infinitivo
c. Je ne peux $m$ 'empêcher de rire.
idem
d. En le voyant, j'ai pensé à toi.
próclise ao gerúndio
e. Donne-lui son cadeau.
enclise ao imperativo

O espanhol, o catalão e o italiano apresentam um sistema de colocação dos pronomes clíticos condicionado pela morfologia verbal, tal como o francês, mas a ênclise ocorre com as formas não finitas do verbo (infinitivo e gerúndio) e com o imperativo, enquanto a próclise ocorre regularmente com as formas finitas do verbo.

Espanhol
(3) a. Le pedí que me lo contara.
próclise ao verbo finito
b. Tengo que contarte algo.
ênclise ao infinitivo
c. Queremos seguir viéndolos juntos.
ênclise ao gerúndio
d. Dáselo a tu hijo.
enclise ao imperativo

Embora o fator morfológico (particularmente a oposição entre formas verbais finitas e não finitas) não deixe de ter relevância para a colocação dos pronomes clíticos no português europeu, são fatores de natureza sintática os que se revelam dominantes. ${ }^{1}$ De

\footnotetext{
${ }^{1}$ A morfologia verbal é um fator determinante no que diz respeito à mesóclise (i.e. a colocação do pronome clítico numa posição interna à forma verbal, como em: contar-te-ia, contar-te-ei). Este tipo de colocação dos pronomes clíticos é uma variante da ênclise associada à especificidade da morfologia do
} 
facto, em contraste com o francês, o italiano, o espanhol, o catalão e o português brasileiro, o sistema do português europeu apresenta próclise e ênclise quer em frases finitas quer em frases não finitas, com as duas ordens em distribuição complementar nas frases fintas, mas em variação livre em alguns tipos de orações infinitivas. Nas frases (4a) e (4c), a colocação proclítica seria agramatical e na frase (4b) seria agramatical a ênclise. As frases (4d-e) ilustram, pelo contrário, um contexto que torna possível a variação entre próclise e ênclise com o infinitivo simples.

\section{Português europeu}

(4) a. Ela contou-me tudo.

ênclise ao verbo finito

b. Eu também lhe disse a verdade. próclise ao verbo finito

c. Não pude impedir-me de rir. ênclise ao infinitivo

d. Não parou de se queixar o tempo todo. próclise ao infinitivo

e. Não parou de queixar-se o tempo todo. ênclise ao infinitivo

Alguns dos fatores que determinam a colocação enclítica ou proclítica no português europeu são fáceis de identificar, em particular a oposição entre orações principais e subordinadas finitas e a oposição de polaridade entre frases afirmativas e negativas.

Português europeu

(5) a. Ao sábado, geralmente vejo-os.

b. É possível que os veja no sábado.

ênclise em oração principal

c. As laranjeiras regam-se.

d. As oliveiras não se regam. próclise em oração subordinada finita ênclise em frase afirmativa próclise em frase negativa

As frases negativas e as orações completivas finitas são os dois domínios em que, desde mais cedo, as crianças adquirem o padrão de colocação proclítico (\#\#\#16 A aquisição dos pronomes clíticos no português L1). As oposições afirmação/negação, principal/subordinada (finita) são totalmente estranhas à colocação dos pronomes clíticos na maior parte das línguas românicas contemporâneas, mas eram relevantes tanto no português como noutras línguas românicas medievais, conforme se ilustra em (6) e (7) com exemplos do catalão e do espanhol (cf. Granberg 1988; Castillo Lluch 1996; Fischer 2002; Martins 1994; Batllori/Iglésias/Martins 2005; Nieuwenhuijsen 2006; Bouzouita 2008a; 2008b).

futuro e condicional (cf. Roberts 1992; Duarte/Matos 2000; Roberts/Roussou 2002; 2003; OltraMassuet/Arregi 2005). A mesóclise é, no português europeu contemporâneo, própria da língua escrita e de registos orais formais. Foi comum às línguas ibéricas medievais mas sobrevive hoje apenas no português europeu, que neste aspeto se distingue do galego (Álvarez/Xove 2002). Cf. final da secção 2.2. 
Catalão medieval

(6) a. Los cathalans vengueren a Curial e digueren- $l i$ quinys paraments volia

b. Melchior respòs que li playa.

c. Vós no $m$ 'avets fet res.

(Curial e Güelfa; Ferrando 2007, 105, 134)

Espanhol medieval

(7) a. E en aquel tienpo el rey pagava se mucho de caçar com aves

b. E el rrey dixo que les perdonava todos los enojos que le avian fecho fasta alli

c. E don Joan non lo quiso fazer

(Gran Crónica de Afonso XI; Catalán 1977, 18, 19)

A secção 2 deste capítulo aborda o tema da colocação dos pronomes clíticos no português europeu numa perspetiva sincrónica, enquanto a secção 3 o faz numa perspetiva diacrónica (que integra dados de variação sincrónica). O tópico principal das secções 2 e 3.1 é a distribuição da próclise e da ênclise, enquanto a secção 3.2 é dedicada ao fenómeno da interpolação (Chenery 1905; Ramsden 1963), i.e. a possibilidade de um clítico pré-verbal ocorrer separado do verbo por outros constituintes. A secção 4 oferece algumas observações conclusivas.

\section{2 Ênclise e próclise no português europeu contemporâneo}

Nesta secção traça-se um quadro geral, sumário, da colocação dos pronomes clíticos no português europeu contemporâneo (2.1). De seguida, discutem-se alguns casos de aparente variação entre próclise e ênclise, em frases finitas, com o objetivo de mostrar que diferentes linearizações correspondem a diferenças de estrutura e de interpretação (2.2). Deixa-se fora do âmbito desta secção a questão da subida dos pronomes clíticos, que será brevemente abordada, numa perspetiva diacrónica, no final da seccão $3.3 .^{2}$

\subsection{Quadro geral da distribuição da ênclise e da próclise}

A ênclise e a próclise estão em distribuição complementar nas frases que apresentam o verbo em forma finita. Na sequência textual em (8), o primeiro pronome clítico é obrigatoriamente proclítico porque ocorre dentro de uma oração subordinada e o segundo é necessariamente enclítico por pertencer a uma oração principal.

\footnotetext{
${ }^{2} \mathrm{O}$ termo subida do clítico designa os casos em que o pronome clítico é extraído da oração infinitiva e cliticiza ao verbo que a seleciona como complemento. As ordens com e sem subida do clítico, exemplificadas respetivamente em (i) e (ii), são ambas admitidas no padrão contemporâneo.

(i) Este projeto de investigação é do mais avançado que se pode encontrar no jornalismo mundial. (Expresso online, 04.04.2016, Pedro Santos Guerreiro)

(ii) Não se trata de gerir informação, mas de poder confirmá-la, estudá-la, aprofundá-la, discernir entre o que é lícito e o que é duvidoso. (Expresso online, 04.04.2016, Pedro Santos Guerreiro)
} 
(8) Ela é tecedora de teias que outros usam. É uma aranha vegetariana, não come carne. Os outros que $a$ comam, isso é com eles. Os outros comem-na, isso é connosco. (Expresso online, 04.04.2016, Pedro Santos Guerreiro)

A sequência textual em (9), atesta além da oposição principal/subordinada (Quando $\underline{o s}$ encontro/pergunto-lhes), as oposições entre frase afirmativa/frase negativa (pergunto-

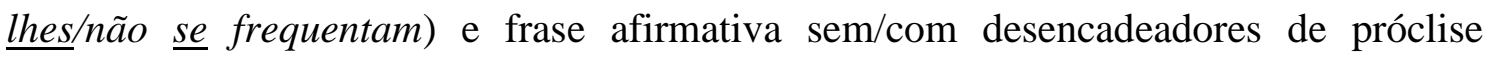
(pergunto-lhes/talvez até se detestem).

(9) Quando os encontro pergunto-lhes «olha lá, o que está a fazer o fulano de tal?» e nunca sabem dos colegas, não se frequentam, talvez até se detestem. (Expresso, 28.03.2015)

Do mesmo modo, nas frases afirmativas em $(10 \mathrm{a}-\mathrm{b})$ só a ênclise é possível, seja em oração principal, como (10a), ou coordenada, como (10b); mas nas orações subordinadas finitas em $(11 \mathrm{a}-\mathrm{d})$ só a próclise é possível. A próclise é também a única opção nas frases negativas em (12a-e) e nas frases (13a-1), nas quais ocorrem antes do verbo quantificadores (muito, pouco, todos), sintagmas QU- (como, o que) e advérbios que, tal como os quantificadores e as palavras QU-, não são compatíveis com a colocação enclítica (até, só, lá enfático, também, sempre, já, talvez).

(10) a. Sim, pedi-lhe que ele fizesse de si próprio. (Expresso, 28.03.2015)

b. O crime é inextirpável mas o combate dissuade-o e pune-o. (Expresso online, 04.04.2016, Pedro Santos Guerreiro)

(11) a. Bem sei que se trata de empresas privadas (Expresso online, 04.04.2016, Nicolau Santos)

b. Empresas fantasma permitem perder o rasto ao dinheiro, ao património e a quem os detém. (Expresso online, 04.04.2016, Pedro Santos Guerreiro)

c. Quando se olha para um tubarão, ninguém repara nas rémoras. (Expresso online, 04.04.2016, Pedro Santos Guerreiro)

d. O jornalismo de informação está a cumprir uma função social, como the compete. (Expresso online, 04.04.2016, Pedro Santos Guerreiro)

(12) a. Não se sai incólume de uma viagem destas. (Expresso online, 04.04.2016, Pedro Santos Guerreiro)

b. Nas restantes ditaduras nem se falou do assunto. (Expresso online, 15.04.2016, Daniel Oliveira)

c. Nunca me identifico com a personagem. (Expresso, 13.10.2012)

d. Mas nada daquilo se cola à nossa vida. (Expresso, 07.12.2013)

e. Quando for para o céu - ou para o inferno - ninguém me vai dar uma medalha por ter tocado em 100 países. (Expresso, 05.04.2014)

(13) a. Muito se falou, pouco se disse e nada se resolveu. (CETEMPúblico) 
b. Queria fazer da segurança o tema do Outono, mas todos lhe trocaram as voltas. (CETEMPúblico)

c. Como te atreves?! (Expresso, 01.02.2014)

d. O que $o$ fez voltar ao cinema agora? (Expresso, 28.03.2015)

e. Gosto de tudo e até me descontraiu. (Expresso, 05.04.2014)

f. A função superior de uma investigação jornalística como esta só se completa se o sistema mudar. (Expresso online, 15.04.2016, Pedro Santos Guerreiro)

g. Mas eu insisti, lá $o$ convenci. (Expresso, 28.03.2015)

h. Garcia Lorca também se chamava Frederico. (Expresso, 28.03.2015)

i. O star system sempre me desagradou. (Expresso, 13.10.2012)

j. Muito antes as duas tribos já se matavam. (Expresso, 29.11.2014)

1. Enfim, talvez os métodos da ficção me pudessem levar a uma espécie de autobiografia dirigida a Fellini. (Expresso, 28.03.2015)

A caracterização do conjunto de itens que no português europeu tornam a próclise obrigatória em frases afirmativas (não subordinadas) é a parte do sistema de colocação dos pronomes clíticos que mais resiste a uma descrição simples e integradora. Se a classe das palavras QU- não admite exceções (todos os itens desta classe são desencadeadores de próclise), já para os quantificadores é necessário distinguir dois grupos, o dos determinantes relativos/proporcionais, que impõem a próclise, e o dos determinantes absolutos/cardinais (Fodor/Sag 1982; Higginbotham 1987; Martins 1997), que não têm o mesmo efeito, sendo compatíveis com a ênclise. Além disso, o conjunto dos advérbios que desencadeiam a próclise não corresponde a uma classe semântica particular. Por fim, podem ser fatores puramente estruturais que determinam a colocação dos pronomes clíticos em ênclise ou em próclise. É o caso da oposição entre topicalização (ou outras estruturas de marcação de tópicos) e focalização (\#\#\#14 Ordem dos constituintes frásicos: sujeitos invertidos; objetos antepostos). A mesma palavra, ou constituinte pré-verbal, pode assim aparecer associada ora à ênclise ora à próclise, mas a alternância entre uma e a outra colocação não é livre, como ilustraremos na secção 2.2. (Para uma descrição detalhada da colocação dos pronomes clíticos no português europeu contemporâneo, cf. Martins 2013).

O Quadro 1 identifica os itens lexicais e fatores estruturais que fazem emergir o padrão proclítico nas frases afirmativas, não subordinadas. Os itens que estão marcados com asterisco (*) são os desencadeadores de próclise categóricos, ou seja, os que excluem sempre a ênclise. Quanto aos restantes, os contrastes semânticos que exibem conforme se associam à próclise ou à ênclise decorrem ou de ambiguidade lexical ou do tipo de estrutura sintática em que se integram (podendo ser tópicos, focos contrastivos, marcadores de foco ou marcadores de ênfase). A focalização é um fator estrutural 
Martins, Ana Maria (2016). A colocação dos pronomes clíticos em sincronia e diacronia. In: Ana Maria Martins \& Ernestina Carrilho (eds.), Manual de Linguística Portuguesa. Berlin/Boston: De Gruyter. 401-430.

associado à próclise, não estando portanto limitada a itens lexicais particulares, pelo que na penúltima linha do Quadro 1 não há lugar à apresentação de uma lista. ${ }^{3}$

\begin{tabular}{|c|c|}
\hline $\begin{array}{r}\text { Proclisadores: categóricos* } \\
\text { não categóricos }\end{array}$ & Exemplos \\
\hline 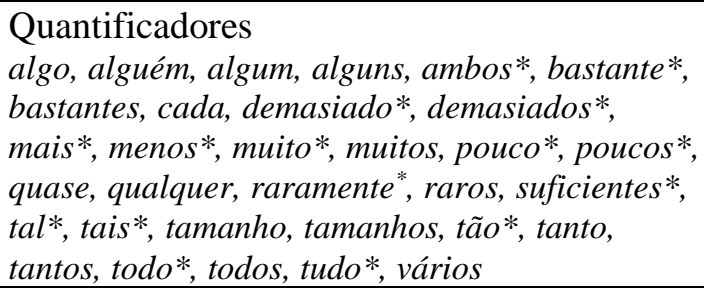 & 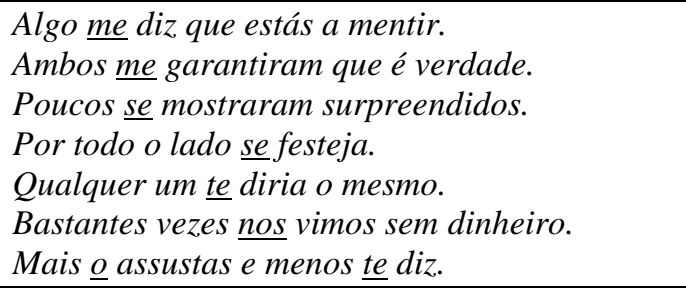 \\
\hline $\begin{array}{l}\text { Marcadores de foco } \\
\text { inclusivos: também } * \text {, até } e^{*}, \text { mesmo }^{*} \\
\text { exclusivos: apenas }{ }^{*}, \text { só }^{*}, \text { somente }^{*}, \text { logo, antes } \\
\text { aspetuais: ainda } *, \text { já }^{*}, \text { quase }^{*}, \text { mal }^{*}, \text { talvez }^{*}\end{array}$ & $\begin{array}{l}\text { Apenas um turista o confrontou. } \\
\text { Até o melro se pôs a cantar. } \\
\text { Logo hoje te tens de ir embora mais cedo. } \\
\text { Ainda te digo mais. } \\
\text { Mal } \underline{\text { vi mas quase me fez cair. }}\end{array}$ \\
\hline $\begin{array}{l}\text { Marcadores de ênfase } \\
\text { bem, até*, sempre*, lá, aí, aqui, logo, já* }\end{array}$ & $\begin{array}{l}\text { Bem o quisemos salvar, mas não conseguimos. } \\
\text { Eu até te contava, mas não posso. } \\
\text { Se fores de comboio, sempre te sai mais barato. }\end{array}$ \\
\hline $\begin{array}{l}\text { Advérbios focalizados } \\
\text { Por exemplo: dêiticos locativos (aí, ali, aqui, cá, } \\
\text { lá), assim, sempre*, logo, agora, depois, melhor, } \\
\text { pior; alguns advérbios em -mente }\end{array}$ & $\begin{array}{l}\text { Assim se fará. } \\
\text { Ali se instalaram e não saíram mais. } \\
\text { Rapidamente se afastou. } \\
\text { Agora te exijo uma resposta. }\end{array}$ \\
\hline Constituintes não-adverbiais focalizados & $\begin{array}{l}\text { De notícias se faz o nosso mundo. } \\
\text { Se o livro saiu bem, a si se deve. } \\
\text { Com a verdade me enganas. } \\
\text { Não fico em casa, isso te garanto. }\end{array}$ \\
\hline $\begin{array}{l}\text { Interrogativas e exclamativas QU- } \\
\text { que }^{*}, \text { o que } e^{*}, \text { quem }^{*}, \text { onde }^{*}, \text { quanto }^{*}, \text { como }^{*}, \\
\text { quando*, por que* }\end{array}$ & $\begin{array}{l}\text { Quem te contou? } \\
\text { Como ele me irrita! }\end{array}$ \\
\hline
\end{tabular}

Quadro 1: Indutores de próclise em frases simples afirmativas (cf. Martins 2013).

Nas orações gerundivas, o fator mais importante relativamente à distribuição da próclise e da ênclise é a polaridade da frase. As orações gerundivas afirmativas normalmente apresentam ênclise, enquanto as orações gerundivas negativas apresentam próclise.

\footnotetext{
${ }^{3}$ Para além dos casos identificados no Quadro 1, a próclise pode ainda ocorrer associada à expressão da afirmação enfática, como se exemplifica em (i)-(ii) abaixo. Também neste caso não há, em princípio, restrições quanto à natureza do constituinte que ocorre à esquerda do verbo e do clítico, mas este tipo de estrutura é infrequente no português contemporâneo. Nas estruturas de afirmação enfática não se põe em destaque o constituinte pré-verbal (como na focalização), mas sim o valor de verdade da asserção.

(i) Isabel dos Santos chamou «diploma BPI» a um decreto, aprovado pelo Governo e promulgado pelo Presidente da República, e que transcreve orientações europeias no sentido de serem eliminados os limites aos direitos de voto nas instituições financeiras. Ela $o$ disse e não houve uma voz autorizada que a viesse contestar. (Expresso online, 22.04.2016, Nicolau Santos)

(ii) Passos Coelho tem nas mãos muito mais que o destino da PT. E já fez de Pilatos uma vez: não pode fazer duas. Desta vez ou escolhe defender o país ou não. A história o julgará. (Expresso, 11.10.2014, Nicolau Santos).
} 
(14) a. Desde então, o grupo de jornalistas tem investigado milhões de documentos, juntandolhes ainda mais informação, para criar aquilo a que chamamos os «Panama Papers». (Expresso online, 04.04.2016, Pedro Santos Guerreiro)

b. Mas a Associação de Defesa dos Utentes de Sangue está determinada a levar o problema até às mais altas instâncias, não se importando «de perder batalhas para ganhar guerras». (CETEMPúblico)

A presença de um dos itens identificados no Quadro 1 como proclisador tem numa gerundiva afirmativa o mesmo efeito que numa frase finita afirmativa.

(15) a. Afirmam que, já tendo feito uma retirada no terreno e já se tendo comprometido a novas retiradas, o lado «pragmático» de Netanyahu florescerá agora e as suas inibições «ideológicas» desvanecer-se-ão. (CETEMPúblico)

b. Entretanto, a questão dos deputados honorários parece estar em banho-maria, só se prevendo que seja retomada na próxima conferência de líderes. (CETEMPúblico)

Nas orações infinitivas interagem diferentes fatores para determinar quando ocorre a ênclise ou a próclise. Considerando apenas os que são específicos dos domínios infinitivos, será relevante se o infinitivo é simples ou flexionado, se a oração infinitiva é ou não introduzida por preposição e qual a preposição particular que a introduz, como sintetiza o Quadro 2. Embora o infinitivo simples e o infinitivo flexionado tenham um comportamento semelhante em alguns aspetos (por exemplo, a ênclise com as preposições a e com, e, noutros casos, a possibilidade de variação entre próclise e ênclise), o infinitivo flexionado aproxima-se mais das frases finitas ao reduzir a variação próclise/ênclise ao contexto particular das orações introduzidas pela preposição em. De resto, a próclise e a ênclise estão em distribuição complementar nas orações de infinitivo flexionado, tal como nas frases finitas. Pelo contrário, a variação próclise/ênclise é muito característica das orações de infinitivo simples, ainda que seja contextualmente condicionada.

\begin{tabular}{|c|c|c|c|c|c|}
\hline \multicolumn{3}{|c|}{ Infinitivo Simples } & \multicolumn{3}{|c|}{ Infinitivo flexionado } \\
\hline Ênclise & $\begin{array}{c}\text { Variação } \\
\text { Próclise/Ênclise }\end{array}$ & Próclise & Ênclise & $\begin{array}{c}\text { Variação } \\
\text { Próclise/Ênclise }\end{array}$ & Próclise \\
\hline $\begin{array}{l}\text { Orações não } \\
\text { introduzidas por } \\
\text { preposição, ou } \\
\text { introduzidas } \\
\text { pelas preposi- } \\
\text { ções } a \text { e com } \\
\text { (sem } \\
\text { proclisadores) } \\
\text { Interrogativas } \\
\text { indiretas (sem } \\
\text { proclisadores) }\end{array}$ & $\begin{array}{l}\text { Orações } \\
\text { introduzidas pelas } \\
\text { preposições de, } \\
\text { para, por, em, sem } \\
\text { (sem proclisadores) } \\
\text { Orações infinitivas } \\
\text { negativas (com a } \\
\text { negação expressa } \\
\text { por não) } \\
\text { Orações } \\
\text { introduzidas pelos } \\
\text { pronomes e } \\
\text { advérbios relativos } \\
\text { ou interrogativos } \\
\text { (sem proclisadores) }\end{array}$ & $\begin{array}{l}\text { Orações que } \\
\text { incluem } \\
\text { proclisadores } \\
\text { (exceto } n \tilde{a} o \text { ) }\end{array}$ & $\begin{array}{l}\text { Orações não } \\
\text { introduzidas por } \\
\text { preposição, ou } \\
\text { introduzidas } \\
\text { pelas preposi- } \\
\text { ções } a \text { e com, } \\
\text { (sem } \\
\text { proclisadores) } \\
\text { Frases simples } \\
\text { exclamativas } \\
\text { (sem } \\
\text { proclisadores) }\end{array}$ & $\begin{array}{l}\text { Orações } \\
\text { introduzidas pela } \\
\text { preposição } \mathrm{em}\end{array}$ & $\begin{array}{l}\text { Orações } \\
\text { introduzidas } \\
\text { pelas } \\
\text { preposições } \\
\text { de, para, após, } \\
\text { até, sem } \\
\text { Orações que } \\
\text { incluem } \\
\text { proclisadores }\end{array}$ \\
\hline
\end{tabular}




\begin{tabular}{|l|l|l|l|l|}
\hline & $\begin{array}{l}\text { Orações } \\
\text { dependentes de } \text { ter } \\
\text { que, haver que }\end{array}$ & & & \\
\hline
\end{tabular}

Quadro 2: Distribuição da próclise e da ênclise em orações infinitivas (Martins 2013).

Em (16) e (17) exemplifica-se a variação entre próclise e ênclise que o português europeu permite quando o infinitivo é simples e introduzido por uma preposição diferente de $a$ ou com. Embora as duas ordens sejam consideradas padrão, os falantes têm normalmente preferência por uma ou outra em função de cada preposição particular. $^{4}$

(16) a. Não fiz tal comparação nem tinha de $a$ fazer, pois não era esse o objecto do meu texto. (CETEMPúblico)

b. Essa pergunta terá de fazê-la ao senhor Américo Amorim. (CETEMPúblico)

(17) a. Com salários em atraso, as 250 operárias haviam contratado autocarros para deslocarse em protesto até à presidência do Governo Regional, mas os motoristas não compareceram. (CETEMPúblico)

b. É o caso de doze alunos da universidade privada Jayabaya, de Jacarta, que, relata a agência Lusa, estão a encontrar dificuldades para se deslocar a Manila, onde deveriam tomar parte na Conferência de Estudantes da Ásia-Pacífico. (CETEMPúblico)

Diferentemente do português brasileiro, as variedades africanas do português têm essencialmente o sistema de colocação dos pronomes clíticos descrito nesta secção, mas com uma pequena margem de variação próclise/ênclise em contextos que no padrão europeu apenas permitem uma das ordens . Essa pequena margem de variação também se encontra nos dialetos do português europeu. Dou aqui exemplos de próclise em contextos de ênclise, em frases finitas. Mas também ocorre a situação inversa (i.e. ênclise em frases com proclisadores), quer no português dialetal quer nas variedades africanas do português (\#\#\#2 $\mathrm{O}$ português em contacto em África; e veja-se a observação sobre o «grupo de controlo» em \#\#\#16 A aquisição dos pronomes clíticos no português L1). ${ }^{5}$

\footnotetext{
${ }^{4}$ Gillier (2009) analisou um pequeno corpus representativo de dois autores literários, Jorge de Sena e José Cardoso Pires, e mostrou que têm comportamentos distintos relativamente às orações de infinitivo simples, introduzidas por preposição. Enquanto em José Cardoso Pires ocorre sempre a próclise com as preposições de, para e sem, registando-se ênclise a par da próclise apenas com a preposição por, Jorge de Sena apresenta variação entre ênclise e próclise com todas as preposições (i.e. de, para, sem e por), sendo a ênclise a opção mais frequente. Cf. nota 6, na secção 2.2.

${ }^{5}$ É possível analisar algumas das frases em (18) como casos de afirmação enfática (cf. nota 3, acima).
} 
(18) a. Mano, ela me cansou. (Português de Moçambique; Justino 2010)

b. Eles se encontram marginalizados. (Português de Moçambique; Mapasse 2005, 67)

c. Me disseste que era segredo, não meterias a foto dele no facebook, me mentiste. (Português de Angola; Domingos 2010)

d. Fuguh, vi essa foto e te identifiquei bem rápido. (Português de Angola; Domingos 2010)

e. Eu consegui conviver com a população, consegui mergulhar onde há pobreza em Nigéria, as pessoas me olhavam com bons olhos (Português de São Tomé; Gonçalves 2009)

f. No meu caso eu não estou a conseguir envolver com nenhum homem porque homem são-tomense é muito maldoso. Eles acham que nós somos escrava deles, nos maltratam muito. (Português de São Tomé; Gonçalves 2009)

g. Me enganaste?! (Português dialetal; CORDIAL-SIN, Melides, Alentejo)

h. A gente the chama os miolinhos. (Português dialetal; CORDIAL-SIN, Serpa, Alentejo)

i. Bem disse o rapaz: «Se mete como está este coiso». (Português dialetal; CORDIALSIN, Alvor, Algarve)

j. Às vezes me junto com os meus amigos (Português dialetal; CORDIAL-SIN, Santo André, Vila Real)

1. Depois os foles - lhe chamam - enchem-se. (Português dialetal; CORDIAL-SIN, Fiscal, Minho)

m. Homem, tu $o$ viste no outro dia, por que é que queres tornar a ver? (Português dialetal; CORDIAL-SIN, Pico, Azores)

Pela sua complexidade e aquisição relativamente tardia (Costa/Fiéis/Lobo 2014), talvez o sistema de colocação dos pronomes clíticos aqui descrito integre de forma equilibrada uma pequena margem de variação estável, que só deixa de ser visível por pressão normativa. Considerando a mudança ocorrida no português brasileiro, pode pensar-se que num contexto de línguas em contacto e de menor pressão normativa se ultrapassou o limite de variação estável e o sistema se tornou demasiado instável para poder ser adquirido na sua configuração original. Quer dizer, a variabilidade no input terá ultrapassado um certo limite sensível para a aquisição de L1, conduzindo à simplificação radical que vemos no sistema de colocação dos pronomes clíticos do português brasileiro.

\section{2 Ênclise, próclise e interação entre sintaxe e interpretação}

Só alguns dos itens listados no Quadro 1 desencadeiam sempre a próclise (i.e. os que estão marcados com asterisco). Relativamente aos que não são proclisadores categóricos, importa esclarecer que não há variação livre entre próclise e ênclise, como veremos nesta secção através de alguns exemplos.

Os dêiticos locativos aqui, aí, ali, cá, lá podem ser facilmente topicalizados ou focalizados contrastivamente (\#\#\#14 Ordem dos constituintes frásicos: sujeitos 
Martins, Ana Maria (2016). A colocação dos pronomes clíticos em sincronia e diacronia. In: Ana Maria Martins \& Ernestina Carrilho (eds.), Manual de Linguística Portuguesa. Berlin/Boston: De Gruyter. 401-430.

invertidos; objetos antepostos). Em ambos os casos são movidos para posições na periferia esquerda da frase, precedendo portanto o verbo. Quando estão focalizados são desencadeadores de próclise, como acontece com os focos contrastivos antepostos em geral. Quando ocupam uma posição de tópico não têm qualquer efeito sobre a colocação dos pronomes clíticos, sendo portanto compatíveis com a ênclise. As frases com dêitico locativo e próclise são interpretativamente diferentes das frases com dêitico locativo e ênclise, o que é independente do dêitico em si, decorrendo antes das diferenças interpretativas entre estruturas de topicalização e estruturas de focalização. Está em causa, portanto, uma diferença sintática, estrutural, e não lexical. A inclusão dos dêiticos locativos aqui, aí, ali, cá, lá no Quadro 1, acima, deve-se ao facto de serem itens que ocorrem frequentemente focalizados e atuam, nesta circunstância, como proclisadores. A sequência textual em (19) mostra-nos o dêitico locativo ali a ocorrer primeiro como tópico e depois como foco contrastivo. Como tópico, não desencadeia próclise. Por isso, se substituíssemos o verbo começar pelo verbo iniciar-se, ocorreria a ênclise. Quando o dêitico ali está focalizado, a próclise torna-se obrigatória, como se vê na frase: Ali se sentem de novo mulheres. As frases em que ali está focalizado (mas não a frase em que ali é um tópico) são parafraseáveis por uma estrutura clivada, como é próprio das estruturas de focalização contrastiva: 'É ali que constroem, por instantes, fragmentos de liberdade'; 'É ali que, por instantes, se sentem de novo mulheres'.

Em (19), os parêntesis retos e elementos associados foram adicionados ao texto original. As etiquetas «Top» e «Foc» correspondem a Tópico e Foco Contrastivo.

(19) «3 Horas para Amar» é o título do documentário realizado com reclusas do Estabelecimento Prisional de Santa Cruz do Bispo, em Matosinhos, assinado por Patrícia Nogueira (...). Patrícia propõe uma viagem tão fascinante quanto perturbadora na companhia de quatro mulheres disponíveis para falarem da vida que tinham «lá fora»e da que passaram a ter no interior da cadeia. [Ali, $]_{\text {Top }}$ a rotina começa [inicia-se] às $8 \mathrm{~h}$ quando

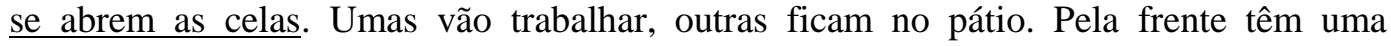
imensidão de tempo. Falam dos que não estão e, afinal, nunca deixam de povoar aqueles quotidianos. Os maridos, os companheiros, os filhos, as mães, os amigos que às vezes já o não são tanto. Uma vez por mês, durante três horas, as reclusas abrangidas pelo regime de Visitas Íntimas, têm à sua disposição um compartimento da prisão. [Ali] Foc_constroem, por instantes, fragmentos de liberdade. [Ali, $]_{\text {Foc }}$ por instantes, se sentem de novo mulheres. (Expresso online, 05.01.2016, Valdemar Cruz)

Outros advérbios além dos dêiticos locativos podem ocupar quer uma posição de foco contrastivo quer uma posição de tópico na periferia esquerda da frase. Nalguns casos, daí decorrem contrastes interpretativos ainda mais marcados do que no exemplo (19). 
Martins, Ana Maria (2016). A colocação dos pronomes clíticos em sincronia e diacronia. In: Ana Maria Martins \& Ernestina Carrilho (eds.), Manual de Linguística Portuguesa. Berlin/Boston: De Gruyter. 401-430.

Assim, em (20), podemos ver que o advérbio loucamente tem a interpretação de advérbio de modo (modificador do sintagma verbal) quando focalizado, como em (20a), mas é interpretado em (20b) como advérbio orientado para o sujeito. A diferente posição do pronome clítico nas duas frases assinala que só na primeira há focalização.

(20) a. Loucamente $a$ amou. (= 'foi loucamente que a amou')

b. Loucamente, amou- $a$. (= 'foi louco ao amá-la')

O advérbio bem precede o verbo em frases com ênclise quando é um tópico, como em (21a), frase que apresenta topicalização do sintagma verbal com apagamento do verbo. Neste caso, bem tem a interpretação de advérbio de modo (modificador do sintagma verbal) e pode ser reduplicado, pois a posição de tópico é recursiva. Como marcador de ênfase, por outro lado, bem, apresenta-se despojado do seu conteúdo semântico básico, ocorre na periferia esquerda da frase e desencadeia próclise, conforme se vê em (21b). Como marcador de ênfase, bem não pode ser reduplicado, o que evidencia que também neste caso há uma diferença estrutural que se associa ao contraste semântico e à oposição entre ênclise e próclise.

(21) a. Bem, (bem), come-se naquele restaurante. (= Comer bem, (comer bem), come-se naquele restaurante')

b. Bem me podias oferecer o jantar. (= 'Podias oferecer-me o jantar!')

Há advérbios que não podem ser focalizados. É o caso dos evidenciais e alguns avaliativos, como se exemplifica em (22) com o evidencial obviamente e em (23) com o avaliativo surpreendentemente. Também não sendo marcadores de ênfase nem marcadores de foco, estes advérbios são incompatíveis com a próclise, daí a agramaticalidade de (22b) e (23b). O outro facto interessante em relação a estes advérbios é que a interpretação das frases em que ocorrem torna claro que não são tópicos (quer dizer, não é possível interpretá-los como aboutness topic/Sujeito lógico de uma estrutura de Predicação, numa perspetiva semântica, nem como informação conhecida, partilhada ou familiar, numa perspetiva pragmático-discursiva). A ênclise não depende pois da presença de um tópico na frase nem os constituintes que precedem o verbo numa frase com ênclise têm de ser tópicos.

(22) a. Obviamente demito-o! (Humberto Delgado, sobre Salazar)

b. *Obviamente $o$ demito. 
(23) a. Surpreendentemente, amamo-nos.

b. *Surpreendentemente nos amamos.

No domínio dos quantificadores também se observa a distinção entre proclisadores categóricos e não categóricos (cf. Quadro 1). Se observarmos o comportamento do quantificador muitos, que ora se associa à ênclise ora se associa à próclise, voltamos a constatar a interdependência entre sintaxe e interpretação. Ou seja, não são semanticamente equivalentes frases que, à primeira vista, se distinguem apenas pela posição do pronome clítico relativamente ao verbo.

O quantificador muitos pode ser um determinante absoluto/cardinal, caso em que refere um conjunto de indivíduos ou entidades particulares (identificáveis e avaliados quantitativamente em termos absolutos), ou um determinante relativo/proporcional, caso em que é puramente quantificacional, sem a componente referencial, e especifica uma quantidade avaliada relativamente a um certo valor de referência (cf. Fodor/Sag 1982; Higginbotham 1987; Martins 1997). Como determinante absoluto, muitos pode ser parte do constituinte tópico das frases categóricas (\#\#\#14 Ordem dos constituintes frásicos: sujeitos invertidos; objetos antepostos) e associa-se à ênclise. Como determinante relativo, o quantificador muitos associa-se à próclise em estruturas afins às estruturas de focalização. A distinção relevante está exemplificada em (24). Enquanto na frase (a) se diz que há muitas pessoas que nunca falham a meia maratona de Lisboa (pessoas que poderiam ser identificadas consultando a base de dados de inscrições no evento), a frase (b) estabelece apenas que o número de pessoas que se inscreve anualmente na meia maratona de Lisboa é elevado, nada revelando sobre se há ou não repetição dos mesmos participantes ano após ano.

(24) a. Muitas pessoas inscrevem-se todos os anos na meia maratona de Lisboa.

(= 'pessoas há que se inscrevem todos os anos na meia maratona de Lisboa e não são poucas')

b. Muitas pessoas se inscrevem todos os anos na meia maratona de Lisboa.

(= 'é sempre elevado o número de participantes na meia maratona de Lisboa, relativamente a números de referência para este tipo de evento')

Esta diferença de interpretação torna-se particularmente clara no par de frases em (25). A frase (25b) é semanticamente estranha porque num mundo de seres mortais o mesmo indivíduo não pode suicidar-se ano após ano. Num mundo alternativo, a frase (26), com o nome «marcianos» a substituir «pessoas», parece, no entanto, perfeitamente aceitável. 
(25) a. Muitas pessoas se suicidam todos os anos. (= 'é elevado o número de pessoas que anualmente comete suicídio')

b. \#Muitas pessoas suicidam-se todos os anos. (= 'há pessoas que todos os anos se suicidam e não são poucas')

(26) Muitos marcianos suicidam-se todos os anos e reaparecem depois rejuvenescidos.

\section{Aspetos diacrónicos da colocação dos pronomes clíticos (estabilidade e mudança)}

O português dos séculos XIII e XIV não é muito diferente do português contemporâneo no que diz respeito à distribuição da próclise e da ênclise, como mostram os fragmentos da Crónica Geral de Espanha de 1344 que se apresentam a seguir (cf. Cintra 1990). Continuamos a ver a próclise ocorrer em frases negativas (e.g. Nõ vos está bem), em orações subordinadas (e.g. E elles disserom que lho tiinham em grande mercee) e nas frases afirmativas em que precedem o verbo os mesmos itens que são desencadeadores de próclise no português europeu contemporâneo (e.g. ainda vos ẽvya hũa tenda; $\underline{\text { ambos }}$ $\underline{\text { vos }}$ acordaredes no melhor; E assi vos vingaredes). Fora destes casos, é a ênclise que ocorre maioritariamente nas frases finitas, embora a próclise também seja possível (e.g. E dom Alvaro Fernandez lhe disse). Ou seja, os contextos de próclise obrigatória no português contemporâneo também o eram no português medieval (neste aspeto há estabilidade ao longo do tempo), mas nos contextos em que só a ênclise ocorre no português contemporâneo, pode observar-se variação entre ênclise e próclise no português medieval. A frequência relativa de uma ou outra opção muda bastante ao longo do tempo, como se verá na secção 3.1. Nos séculos XIII e XIV a ênclise é, na ausência de proclisadores, o padrão dominante nas frases finitas afirmativas. Como as sequências textuais em (27) a (29) também mostram, uma outra diferença entre o português medieval e o português contemporâneo observa-se nos contextos de próclise obrigatória. No português medieval, os pronomes clíticos pré-verbais podiam estar separados do verbo por diferentes tipos de constituintes (e.g. despois que me eu de vos parti). Este tipo de linearização recebe o nome de interpolação, fenómeno de que tratará a secção 3.2 .

Nos exemplos (27) a (29), todos os clíticos estão destacados a negrito, os constituintes interpolados estão sublinhados, a próclise sem proclisadores está assinalada por maiúsculas pequenas e todos os enclíticos estão em itálico. 
(27) E, quando chegarõ ante el rei, dom Alvaro Fernandez e Pero Vermuiz beyjarõlhe as mãaos por o Cide e disseronlhe:

- Senhor! Roy Diaz, o Cide, SE ẽvya ẽcomendar ẽ vossa mercee, como de senhor natural, e tem que lhe fezestes muyta mercee em quanta honrra e bẽ mandastes fazer a sua molher e a suas filhas. E, despois que me eu de vos parti, vẽceu o Cide hũa batalha de mouros, de que era senhor el rei Unez, filho de Miraamolỹ de Marrocos, que o veeo cercar ẽ Vallença cõ L mil cavalleiros. E o Cide sayu a elle e venceuho ẽ cãpo. E, do seu quinto que elle hi guaanhou, ẽvyavos estes trezentos cavallos.

E el rei foi muy alegre por a boa vẽtuira do Cide e louvou / [248d] muito tam nobres doas como lhe ẽvyava e disse:

- Certo nunca foy ẽ Espanha vassallo que tantas boas doas mandasse a senhor.

E dom Alvaro Fernandez LHE disse:

- Senhor, ainda vos ẽvya hũa tenda que foy del rei Unez, que nunca a homẽ vyo melhor.

E el rey mandouha logo armar e entrou dentro em ella com todos seus ricos homẽes. E el rei com todollos outros diserom que nunca virõ tenda tam nobre. E el rey louvou muito o Cide e todollos seus cavalleiros e gradeceolhe muyto o grande presente que lhe ẽviara. E mandou muy bẽ apousentar dom Alvaro Fernandez e Pero Vermuiz e darlhes todo o que era mester. (Cap. DCXXX; Miranda 2013, 226)

(28) E el rei mãdou por os messejeiros do Cide e disselhes como / [249a] gradecia muyto ao Cide o grande serviço que lhe fazia; e que avya muy grande sabor de o veer e que porem lhe dissessem que lhe mandava elle rogar que o vehesse veer a Requena, ca queria com elle fallar algũas cousas de sua prol, ẽ razom de casamẽtos pera suas filhas, por que os iffantes de Carriõ lhe disserom que casariã com ellas, se elle quisesse, e que a elle parecia que seeriã muy bem casadas cõ elles. E os messejeiros do Cide disseronlhe:

- Senhor, nos bẽ entendemos que o Cide fara todo o que lhe vós mandardes. E, quando vos cõ elle virdes, ambos vos acordaredes no melhor.

$\mathrm{E}$, despois que lhes el rei disse todo o que queria mandar dizer ao Cide, beyjarõlhe as mãaos e espedironsse delle. E el rei mandou logo por os iffantes de Carriõ e disselhes todo o que fallara cõ os messejeiros do Cide. E elles disserom que lho tiinham em grande mercee. (Cap. DCXXXI; Miranda 2013, 227)

(29) - Filhos, que foi esto por que mostrades tanta covardice por vista de hũa besta fera? Nõ vos está bem. Devyades de seer nẽbrados como sodes de grande sangue e como sodes meus jenrros e como vos dey duas nobres spadas. E, per todas estas cousas, devyades de perder grande parte do medo.

Destas pallavras ouverom elles mui grande vergonha e firmaron porẽ mais em seus coraçõoes a maa entençõ que avyã fallada. Pero meterõ o feito a jogo. E chamarõ seu tio Sueiro Gonçalvez e sairom cõ elle do paaço. E elle disselhes:

- Que he esto ou como vĩides assy tristes?

E elles disserom:

- Por que nos deshonrrou muy mal o Cide ẽ mandar soltar o leon.

Entom LHE cõtarõ todo o que avyam cuydado. E disselhe:

- Calladedevos e fazede que nõ dades nada porem, de guisa que nõ entenda desto o Cide nem hũa cousa, e atendamos ataa que seja passado / [251c] este arroydo destes mouros que som viindos d'aalem mar. E, despois que esto ouver fym, demandaredes vossas molheres pera as levardes pera vossa terra. E elle nõ avera scusa de vollas nõ dar nem de vos tẽer mais conssigo. E, despois que fordes bem alõgados desta terra, podedes em ellas fazer o que quiserdes. E assi vos vingaredes da deshonrra que vos he feita. (Cap. DCXXXV; Miranda 2013, 231)

A abordagem diacrónica da colocação dos pronomes clíticos que se faz neste capítulo terá por foco as frases finitas. Mas nos excertos da Crónica Geral de Espanha de 1344 
apresentados acima estão destacados todos os clíticos. Nas estruturas com infinitivo, observa-se subida do clítico com verbos de reestruturação (e,g. E el rey mandouha logo armar; filho de Miraamolỹ de Marrocos, que o veeo cercar), o que corresponde ao padrão geral do português medieval, e há próclise ao infinitivo em orações introduzidas pelas preposições de e pera (e.g. avya muy grande sabor de o veer). ${ }^{6}$ A ênclise ao infinitivo ocorre nas frases com verbos de reestruturação quando, em estruturas de coordenação, a elipse do verbo superior torna a subida do clítico impossível ( $E$ mandou muy bẽ apousentar dom Alvaro Fernandez e Pero Vermuiz e darlhes todo o que era mester).

Veremos de seguida, na secção 3.1, que a estabilização da ênclise ao verbo finito nos contextos que começam por ser, historicamente, de variação ênclise/próclise apresenta um percurso surpreendente.

\subsection{A linha evolutiva da ênclise nas frases finitas}

A variação entre próclise e ênclise exemplificada em (27) a (29) mantém-se nos séculos seguintes, como se mostra em (30) a (33), mas a frequência da próclise relativamente à ênclise vai crescendo gradualmente até a próclise se tornar fortemente dominante no século XVI. Também ao longo do período medieval acontecem outras mudanças ligadas à expansão da próclise, que depois do século XIII começa a aparecer em contextos sintáticos que antes a excluíam. A partir do século XIV, um pronome proclítico pode ocorrer na posição inicial de orações coordenadas introduzidas pela conjunção copulativa $e$, como se exemplifica em (31). No século $\mathrm{XV}$, um pronome proclítico pode ocupar a primeira posição da oração principal de uma frase complexa com subordinada anteposta, como em (32). Por fim, já no século XVI, um pronome proclítico pode estar adjacente ao constituinte topicalizado numa estrutura de deslocação á esquerda clítica, ocupando a primeira posição não periférica da frase, como em (33).

Ao longo de todo o período histórico do português (desde os primeiros textos, no final do séc. XII, até hoje), mantêm-se estáveis os contextos de próclise obrigatória.

\footnotetext{
${ }^{6}$ Nos documentos notariais editados por Martins (1994; 2001), que pertencem aos séculos XIII-XVI, há próclise ao infinitivo, sem exceções, com a preposição de. Com a preposição pera há variação entre próclise e ênclise até meados do século XIV e próclise obrigatória a partir daí. Com a preposição $a$ regista-se ênclise até meados do século XIV, após o que só a próclise ocorre. Está por estudar quando, e em que condições, se estabeleceu o atual padrão de variação entre próclise e ênclise em estruturas de infinitivo simples preposicionado, com as preposições de, para, etc., ao mesmo tempo que as orações infinitivas introduzidas pela preposição $a$ parecem ter regredido para o padrão enclítico. Cf. Martins (1994; 2013); Magro (2005).
} 
Martins, Ana Maria (2016). A colocação dos pronomes clíticos em sincronia e diacronia. In: Ana Maria Martins \& Ernestina Carrilho (eds.), Manual de Linguística Portuguesa. Berlin/Boston: De Gruyter. 401-430.

(30) a. e eu enuieyuos dizer per mia carta que me prazia

b. E rey uos me enuiastes dizer per uossa carta que uos desembargariades esse castello de Albofeyra

(Doc. de 1260, Chancelaria de D. Afonso III; Duarte 1986, 87)

(31) a. E el rey abraçouho e beyjouho e fezlhe muy grande honrra.

b. o Cide thes fez muyta honrra e lhes deu grandes doas em ouro e prata e cavallos e outras cousas

(Crónica Geral de Espanha de 1344; Miranda 2013, 229, 228)

(32) a. E quando el-rrei ouvio que elle entrara e que os seus corriam a terra e rroubavom, pesou-lhe muito de os leixarem assi entrar

b. e quando entendeo outra vez de mover esta guerra, the escreveo que fallasse com o duque e com seu irmaão

(Fernão Lopes, Crónica de D. Fernando; Macchi 1975, 418, 427)

(33). a. á pessoa que vos tal disse ou espreveo, pergumtelhe vosalteza omde estava symam afomso

b. aos que imda lá sam, the tenho dado seguros e the mando agora notificar ho voso perdam

(Cartas de Afonso de Albuquerque; Pato 1884, 94, 99)

Entre o século XIII e o século XVI, o português parece estar a evoluir na mesma direção que o espanhol e o catalão relativamente à colocação dos pronomes clíticos, substituindo a ênclise pela próclise nas frases com verbo finito. Mas no século XVII surgem os primeiros sinais de inversão desta tendência e a partir do século seguinte a mudança no sentido da generalização da ênclise torna-se definitiva. O percurso divergente em relação ao espanhol e ao catalão conduzirá ao modelo atual, com eliminação da variação entre próclise e ênclise nas frases finitas (ainda que, fora da variedade padrão europeia, a variação possa ainda observar-se marginalmente, como se mostrou na secção 1.1).

A Figura 1 mostra a retração da ênclise a favor da próclise até ao século XVI e, inversamente, a expansão da ênclise e declínio da próclise a partir do século seguinte (cf. Lawton 1966; Ogando 1980; Silva 1989; Salvi 1990; Kaiser 1992; Martins 1994; 2011; Moraes 1995; Ribeiro 1995; Sousa 2004; Galves/Britto/Sousa 2005; Galves/Sousa 2005; Rocha 2009). Os dados apresentados dizem respeito apenas aos contextos que no português europeu contemporâneo são obrigatoriamente de ênclise, mas exibiam variação entre ênclise e próclise em etapas anteriores da história do português. 
Figura 1: A evolução da ênclise em frases finitas (sem proclisadores), sécs. XIII-XX.

A linha evolutiva traçada na Figura 1 é surpreendente, quer a interpretemos como evidência de uma mudança gramatical cuja orientação se altera radicalmente a meio do percurso quer como uma sequência de dois processos evolutivos em direções opostas. Uma hipótese alternativa é que a gramática fortemente proclítica, de cariz «panibérico», que está representada na maioria dos textos dos séculos XV a XVII tenha estado limitada sociolinguisticamente à classe dominante e aos setores letrados, através dos quais se tornou o modelo da escrita literária e burocrática (Martins 2011; 2015). O período relevante é de forte influência sociocultural e política de Espanha (iniciada muito antes da perda da independência de Portugal, entre 1580 e 1640) e há outros indicadores linguísticos, além da colocação dos pronomes clíticos, que sugerem um efeito significativo do contacto entre português e espanhol no âmbito da corte, da aristocracia e dos escritores literários (cf. Castro 2002; Döhla 2014). Nesta perspetiva, a linha evolutiva representada no Quadro 1 poderá ser enganadora, ao esconder um quadro de mudança linguística mais complexo. Ou seja: entre a elite política, social e cultural ter-se-á desenvolvido uma variedade socioletal que tenderia para a convergência com o espanhol relativamente à generalização da próclise em frases finitas; ao mesmo tempo, desenhava-se e consolidava-se, em outros setores da sociedade, um percurso evolutivo mais direto entre a ênclise (em variação com a próclise) do português medieval e a ênclise (sem variação) do português europeu contemporâneo. A gramática socialmente prestigiada, que favorecia a generalização da próclise, domina de forma esmagadora a produção textual portuguesa entre os séculos 
Martins, Ana Maria (2016). A colocação dos pronomes clíticos em sincronia e diacronia. In: Ana Maria Martins \& Ernestina Carrilho (eds.), Manual de Linguística Portuguesa. Berlin/Boston: De Gruyter. 401-430.

XV e XVII, mas acabará por revelar-se uma «mudança falhada» (Potsma 2010), ao perder progressivamente espaço para a gramática mais enclítica.

A hipótese de que as fontes textuais dificultam a perceção do caminho que, historicamente, conduziu ao padrão de colocação dos pronomes clíticos do português europeu pode ser suportada por paralelos com outras situações. Desde logo o caso do português do Brasil, onde é radical a diferença entre língua falada e língua escrita relativamente à colocação dos pronomes clíticos (cf. Kato/Martins 2016). Por outro lado, se nos mantivermos no âmbito do português europeu, as estruturas de subida do clítico e a mesóclise podem ser exemplos paradigmáticos.

No português medieval, a subida dos pronomes clíticos em estruturas infinitivas era, com raras exceções, o padrão geral. A partir do século XVI, a possibilidade de cliticização ao infinitivo vai ganhando terreno pouco a pouco. A subida do clítico (com cliticização ao verbo finito) e a não subida (com cliticização ao infinitivo) estão exemplificadas em (34). O Quadro 3 mostra como a opção por manter o clítico no interior da oração infinitiva se vai estabelecendo ao longo do tempo, com o correspondente decréscimo da frequência da subida do clítico.

(34) a. ela disse q. não ma pudia dar aqueles dias

b. qdo. fui comfesarme comt[e]i tudo isto ao comfesor

(Inquisição de Lisboa, ano de 1699; Marquilhas 2000, 301, 303)

\begin{tabular}{|l|c|c|}
\hline & Subida do clítico & Cliticização ao infinitivo \\
\hline Afonso de Albuquerque (1462?-1515) & $95 \%$ & $5 \%$ \\
\hline Damião de Góis (1502?-1574) & $100 \%$ & $0 \%$ \\
\hline Fernão Mendes Pinto (1510-1583) & $97 \%$ & $3 \%$ \\
\hline Diogo do Couto (1542-1616) & $94 \%$ & $6 \%$ \\
\hline António Vieira (1608-1697) & $82 \%$ & $18 \%$ \\
\hline Luís António Verney (1713-1792) & $33 \%$ & $67 \%$ \\
\hline Almeida Garrett (1799-1854) & $55 \%$ & $45 \%$ \\
\hline Oliveira Martins (1845-1894) & $0 \%$ & $100 \%$ \\
\hline
\end{tabular}

Quadro 3: Subida dos pronomes clíticos, séculos XVI-XX (Martins 2006).

Observando o Quadro 3, poderia pensar-se que a partir do século XIX a subida do clítico deixa de ser uma opção no português europeu e a cliticização ao infinitivo se generaliza (como aconteceu aliás no português do Brasil). Em geral, a produção literária do século XX dá evidência no mesmo sentido. Mas, na verdade, a informação que se extrai dos textos é enganadora porque os dados que nos fornecem são o resultado de uma forte pressão normativa no sentido de considerar a subida do clítico uma opção 
Martins, Ana Maria (2016). A colocação dos pronomes clíticos em sincronia e diacronia. In: Ana Maria Martins \& Ernestina Carrilho (eds.), Manual de Linguística Portuguesa. Berlin/Boston: De Gruyter. 401-430.

ilegítima ou incorreta. A escolha normativa de uma das opções permitidas pela gramática criou, no aspeto relevante, uma grande distância entre língua escrita e língua falada. De facto, a análise de dados de língua falada revela que a subida do clítico (por oposição à cliticização ao infinitivo) pode atingir, no português europeu contemporâneo, valores percentuais próximos dos da produção escrita do século XVII (cf. Quadro 3), sem que se registe variação regional ou socioletal significativa (Magro 2005; Andrade 2010; Paiva/Barbosa, submetido).

Por fim, uma referência breve à mesóclise, que na norma padrão do português europeu é obrigatória, nos contextos de ênclise, se o verbo estiver no futuro ou no condicional (quer dizer: sintaticamente a mesóclise é uma variante da ênclise que decorre da especificidade da morfologia de futuro e condicional). A mesóclise existe hoje apenas no português europeu (tendo desaparecido do português brasileiro e do galego) e é própria da escrita ou da oralidade formal, estando em geral ausente da fala espontânea. Em registos menos monitorados, não é raro ver emergir variantes não normativas, com ênclise em lugar da mesóclise. Poderia pensar-se que está em causa uma mudança recente, de expressão ainda limitada, no sentido da substituição da mesóclise pela ênclise, paralelamente ao que aconteceu noutras variedades românicas. Ora quando lemos textos medievais verificamos que a variação entre ênclise e mesóclise está presente no português desde o século XIII, sugerindo uma linha de continuidade até às produções não normativas do português contemporâneo. De novo, a estabilização da mesóclise na produção escrita é o resultado da pressão normativa e esconde a variação que a língua tem mantido ao longo do tempo.

(35) Eu te daria um capão assado e uma regueifa e faria-te tudo comer e dar-te-ia em cima ũa copa chea de vinho que bebesses (Primeiro Livro de Linhagens; Piel e Mattoso 1980, 4849)

(36) detremino de o aviar pa [...] ẽ hũu navyo q estou faltando e asim ordenareivos a vida se poder (Post Scriptum; PSCR1145, CLUL 2014)

No exemplo (35), retirado de um texto do século XIII, vemos aparecer a próclise a par da mesóclise e da ênclise, visto que há variação entre ênclise e próclise no português medieval. Surgem assim as três variantes, associadas a formas verbais do condicional, em frases finitas afirmativas. O exemplo (36), com a ênclise a ocorrer em lugar da mesóclise com uma forma verbal do futuro, pertence a uma carta do ano de 1594 (de 
Jerónimo Leitão, capitão da capitania de São Vicente, para o filho, Francisco Leitão), integrada no arquivo digital Post Scriptum. ${ }^{7}$

\subsection{A interpolação}

Embora as configurações de próclise sejam estáveis ao longo do tempo, o português medieval difere do português contemporâneo por permitir (opcionalmente) que os pronomes clíticos ocorram separados do verbo por outros constituintes, como se observou nas sequências textuais em (27) a (29), de onde se extraem as frases (37a-e). Esta descontinuidade entre clítico e verbo recebe o nome de interpolação (cf. Martins 1994; Fiéis 1996; Namiuti 2006; 2008; Magro 2006; 2010a; 2010b). Nos exemplos em (34) os constituintes interpolados estão delimitados pelas palavras em itálico, i.e. o clítico, à esquerda, e o verbo, à direita.

(37) a. E, despois que me eu de vos parti

b. hũa tenda que foy del rei Unez, que nunca $a$ homẽ vyo melhor.

c. nos bẽ entendemos que o Cide fara todo o que lhe vós mandardes. E, quando vos cõ elle virdes, ambos vos acordaredes no melhor.

d. despois que lhes el rei disse todo o que queria mandar dizer ao Cide

e. E elle nõ avera scusa de vollas nõ dar

A interpolação do português medieval só é permitida nos contextos de próclise obrigatória, estando excluída dos contextos de variação próclise/ênclise, mesmo quando nesses contextos ocorre a próclise. Além disso, o marcador de negação predicativa não pode legitimar a interpolação porque nom/não tem um requisito de adjacência ao verbo, do qual só pode ser separado por pronomes clíticos. A dependência entre nom/não e o verbo determina, por outro lado, que o marcador de negação predicativa ocorra frequentemente interpolado, desde que haja um outro proclisador à sua esquerda (cf. (37e), onde a preposição de é o proclisador que legitima a interpolação de nõ). Nas mesmas condições, diferentes tipos de constituintes podem ser interpolados, como ilustrado em (38). Entre eles: o sujeito, modificadores adverbiais, predicados adjetivais e complementos verbais antepostos (próprios das frases com ordem SOV do português medieval), incluindo complementos oracionais com verbo não finito. Na mesma frase pode ocorrer interpolado mais do que um constituinte frásico e não parece haver

\footnotetext{
${ }^{7}$ É possível encontrar algumas ocorrências de ênclise, em lugar da mesóclise, no corpus CETEMPúblico, mas são provavelmente o resultado de erros de digitalização/formatação do corpus. Por exemplo:

(i) Irá-se privilegiar aqueles que tenham maior incidência no índice de preços no consumidor, no sentido de que, pela evolução dos seus preços, se possa aferir das suas margens de lucro. (CETEMPúblico, par=ext206481-eco-96b-2)
} 
condicionamentos quanto à sua extensão e complexidade (embora exemplos como $(38 \mathrm{j}$ 1) sejam infrequentes). Em geral, qualquer constituinte que possa ocorrer à esquerda do verbo e que não esteja topicalizado nem focalizado (i.e. que não pertença à periferia esquerda da frase) pode ser interpolado entre o clítico e o verbo no português medieval.

(38) a. com os lavradores que as ssemeadas teuerẽ (ano de 1472, Martins 2001, 516)

b. E sse as nos comprar nõ quisermos entõ uẽderdelas uos (ano de 1329; Martins 2001, 414)

c. como lhe entregou as terras que lhe de dar avia (Fernão Lopes; Costa 2001, 184)

d. E com todas as pertenças que aos ditos casaaes lhes dereitamẽte pertẽçe (ano de 1522; Martins 2001, 306)

e. ssegundo as elle sempre trouxera (ano de 1472; Martins 2001, 277)

f. todollos adubyos que lhes conpridoiros e neçesareos forem (ano de 1476; Martins 2001, 459)

g. E mjlhor se o elle Jorge Duarte e pessoa depos elles mjlhor poder aver (ano de 1513; Martins 2001, 301)

h. mas nũca achou quẽ the delle nouas allgũas dissese (Demanda do Santo Graal; WOChWEL, ID DSG168, .15)

i. E sse pela uẽtujra uos algẽ a dita vỹa embargar (ano de 1296; Martins 2001, 377)

j. quem quer que lhe sobre elle e parte delle e sobre as ditas casas e qualquer cousa delas algũu embarguo ou empedymento puser (ano de 1540; Martins 2001, 556)

1. Por as sobreditas vinha e oliual e cãpo e mato que lhys assy os sobreditos Prior e Raçoeiros ẽ nome da dita Eigreia de Sam bartholameu escambhadas e pela guisa que suso dito he e declarado ẽ escambho dadas e outorgadas auyã (ano de 1385; Martins 2001, 462)

Embora a interpolação se registe sobretudo em orações subordinadas, é possível encontrá-la também em frases simples e orações principais, desde que um proclisador preceda o verbo. Exemplo disso são as frases em $(39 a-c)$, nas quais a próclise é desencadeada, e a interpolação legitimada, respetivamente pela palavra negativa nunca, pelo quantificador todos e pelo advérbio ainda.

(39) a. e nunca se i homem assentou (José de Arimateia; WOChWEL, ID JAR41, .36)

b. e todos $o$ dantes nom tinhão por tal cavaleiro (José de Arimateia; WOChWEL, ID JAR49, .41)

c. Certas, disse ho scudeiro, ajnda uos oje mujto pessar averrá (Demanda do Santo Graal; WOChWEL, ID DSG131, .12)

No período medieval, a interpolação de não distingue-se da interpolação de outros constituintes por apresentar níveis de frequência muito superiores, como se mostra, com dados extraídos de documentos notariais, nos Quadros 4 e 5. Só a interpolação de não atinge valores de $90 \%$ ou superiores, aparecendo ao longo do período medieval como padrão não marcado nas frases negativas em que há um clítico e um proclisador 
independente de não. Além disso, durante um intervalo de tempo limitado (séculos XVXVII) a interpolação de não, em contraste com a interpolação de outros constituintes, podia ocorrer, ocasionalmente, fora dos contextos de próclise obrigatória (cf. Martins 1994; Namiuti 2006; 2008).

\begin{tabular}{|c|c|c|c|c|}
\hline & Séc. XIII & Séc. XIV & Séc. XV & Séc. XVI \\
\hline clítico-não-verbo & $94,10 \%$ & $96,80 \%$ & $90,70 \%$ & $90,00 \%$ \\
\hline não-clítico-verbo & $5,90 \%$ & $3,20 \%$ & $9,30 \%$ & $10,00 \%$ \\
\hline
\end{tabular}

Quadro 4: Interpolação de não entre os séculos XIII e XVI (Martins 1994).

\begin{tabular}{|c|c|c|c|c|}
\hline & Séc. XIII & Séc. XIV & Séc. XV & Séc. XVI \\
\hline clítico-X-verbo & $66,70 \%$ & $69,10 \%$ & $57,00 \%$ & $51,70 \%$ \\
\hline X-clítico-verbo & $33,30 \%$ & $30,90 \%$ & $43,00 \%$ & $48,30 \%$ \\
\hline
\end{tabular}

Quadro 5: Interpolação de outros constituintes entre os séculos XIII e XVI (Martins 1994).

A interpolação de não mantém-se uma opção gramatical até aos nossos dias, como se exemplifica em (40), e é considerada uma variante padrão (cf. Duarte 2003, 866-867), ainda que não esteja disponível para todos os falantes nem seja a opção mais usada (i.e. a ordem não-clítico-verbo é mais comum que a ordem clítico-não-verbo). Como as frases em (40) também ilustram, continua a ocorrer apenas nos contextos sintáticos que a permitiam no português medieval, o que se deve à estabilidade diacrónica dos contextos proclíticos (descontada a próclise opcional de etapas passadas da história da língua).

(40) a. Os maridos, os companheiros, os filhos, as mães, os amigos que às vezes já $o$ não são tanto. (Expresso online, 05.01.2016, Valdemar Cruz).

b. O que parece ser então verdade? Em poucas palavras, os portugueses não confiam no governo e no parlamento, mas também os não receiam. (Visão, 23.04.2005, António Barreto).

c. Também se $o$ não comeres agora, podes dizer-lhe adeus. (Cardoso Pires ${ }^{4} 1975,37$ )

Enquanto a interpolação de não persiste ininterruptamente até ao português contemporâneo, a interpolação de outros constituintes, com as características acima descritas, deixa de se registar nas fontes escritas a partir do século XVII.

Nos dialetos do português europeu contemporâneo (de Norte a Sul de Portugal e também nas ilhas dos Açores) é possível encontrar interpolação não limitada à palavra não, o que aparentemente indicaria a persistência residual da interpolação medieval fora da variedade padrão (Martins 1994; Barbosa 1996; Hinzelin 2010). Mas Magro (2006; 
2010a; 2010b) demonstrou que não é assim. Por um lado, a interpolação dialetal tem propriedades muito diferentes da interpolação medieval, encontrando-se limitada a palavras que expressam dêixis: pessoal (eu, nós, a gente, ele, ela, eles, elas, a nós), espacial (aqui, ali, aí, cá, lá, para lá, para aí; esta, isto, isso), temporal (agora, depois, então, hoje, ontem), aspetual (ainda, já) e modal (assim). Por outro lado, o tipo de interpolação característico do português dialetal ocorre, de facto, também em autores literários, mas só a partir do século XIX. Ou seja, no século XVII é ainda visível, de forma residual, a interpolação medieval (limitada a autores nascidos na primeira metade do século). A partir daí e ao longo de todo o século XVIII não há interpolação senão do marcador de negação predicativa. No século XIX emerge um outro tipo de interpolação, limitada a pronomes e advérbios dêiticos, que Magro (2006) mostra ser uma inovação. A persistência ao longo do tempo da interpolação de não terá sido o fator que permitiu a inovação, tornando-se assim, de alguma maneira, a ponte entre a interpolação generalizada do português medieval e a nova interpolação associada à dêixis (sem que a última seja a continuação da primeira). Enquanto a interpolação medieval depende estritamente de fatores sintáticos (perdendo-se porque se altera a estrutura funcional da frase e, concomitantemente, as possibilidades de linearização dos constituintes frásicos), a interpolação contemporânea é um fenómeno mais superficial, de metátese morfológica (Harris/Halle 2005), sem deixar de ter uma base sintática (Magro 2006).

O Quadro 6 evidencia o desaparecimento da interpolação medieval no século XVII e a emergência da interpolação de dêiticos no século XIX. Do conjunto de doze autores oitocentistas estudados por Magro (2006), apenas três, Eça de Queiroz, Trindade Coelho e Mário de Sá Carneiro, não apresentam exemplos de interpolação de dêiticos.

\begin{tabular}{|c|c|c|c|c|}
\hline & \multicolumn{2}{|c|}{ autor - data de nascimento } & $\begin{array}{c}\text { interpolação de } \\
n \tilde{a} o\end{array}$ & $\begin{array}{c}\text { interpolação de } \\
\text { outros constituintes }\end{array}$ \\
\hline \multirow{5}{*}{ Século XVI } & Damião de Góis & 1502 & $\operatorname{sim}$ & $\operatorname{sim}$ \\
\hline & Fernão Mendes Pinto & $1510 ?$ & $\operatorname{sim}$ & $\operatorname{sim}$ \\
\hline & Diogo do Couto & 1542 & sim & $\operatorname{sim}$ \\
\hline & Luís de Sousa & 1556 & $\operatorname{sim}$ & $\operatorname{sim}$ \\
\hline & Francisco Rodrigues Lobo & 1579 & sim & $\operatorname{sim}$ \\
\hline \multirow{6}{*}{ Século XVII } & Francisco Manuel de Melo & 1608 & sim & $\operatorname{sim}$ \\
\hline & António Vieira & 1608 & $\operatorname{sim}$ & não \\
\hline & António das Chagas & 1631 & $\operatorname{sim}$ & $\operatorname{sim}$ \\
\hline & Manuel Bernardes & 1644 & $\operatorname{sim}$ & não \\
\hline & José da Cunha Brochado & 1651 & $\operatorname{sim}$ & não \\
\hline & André Barros & 1675 & $\operatorname{sim}$ & não \\
\hline \multirow{4}{*}{ Século XVIII } & Matias Aires & 1705 & $\operatorname{sim}$ & não \\
\hline & Luís António Verney & 1713 & $\operatorname{sim}$ & não \\
\hline & Correia Garção & 1724 & $\operatorname{sim}$ & não \\
\hline & Marquesa de Alorna & 1750 & $\operatorname{sim}$ & não \\
\hline
\end{tabular}


Martins, Ana Maria (2016). A colocação dos pronomes clíticos em sincronia e diacronia. In: Ana Maria Martins \& Ernestina Carrilho (eds.), Manual de Linguística Portuguesa. Berlin/Boston: De Gruyter. 401-430.

\begin{tabular}{|l|ll|l|c|}
\hline \multirow{5}{*}{ Século XIX } & Almeida Garrett & 1799 & $\operatorname{sim}$ & $\operatorname{sim}$ \\
\cline { 2 - 5 } & Alexandre Herculano & 1819 & $\operatorname{sim}$ & $\operatorname{sim}$ \\
\cline { 2 - 5 } & Camilo Castelo Branco & 1825 & $\operatorname{sim}$ & $\operatorname{sim}$ \\
\cline { 2 - 5 } & Júlio Dinis (1839) & 1839 & $\operatorname{sim}$ & $\operatorname{sim}$ \\
\cline { 2 - 5 } & Eça de Queiroz & 1845 & $\operatorname{sim}$ & não \\
\cline { 2 - 5 } & Guerra Junqueiro & 1850 & $\operatorname{sim}$ & $\operatorname{sim}$ \\
\cline { 2 - 5 } & Fialho de Almeida & 1875 & $\operatorname{sim}$ & sim \\
\cline { 2 - 5 } & Trindade Coelho & 1861 & $\operatorname{sim}$ & não \\
\cline { 2 - 5 } & Raul Brandão & 1867 & $\operatorname{sim}$ & sim \\
\cline { 2 - 5 } & Aquilino Ribeiro & 1885 & $\operatorname{sim}$ & não \\
\cline { 2 - 5 } & Mário de Sá Carneiro & 1890 & $\operatorname{sim}$ & sim \\
\cline { 2 - 5 } & João de Araújo Correia & 1899 & $\operatorname{sim}$ & \\
\hline
\end{tabular}

Quadro 6: Interpolação entre os séculos XVI e XIX (Magro 2006; Martins 1994; Namiuti 2006; 2008).

Os exemplos apresentados em (41) e (42) são extraídos de Magro (2006, 98, 100-102, 112-113, 178-179, 233) e comprovam que a interpolação encontrada nos autores do século XIX e a interpolação dialetal atestada no corpus CORDIAL-SIN são da mesma natureza. Tanto nos dados dialetais em (41) como nos dados literários em (42), vemos interpolados dêiticos pessoais, locativos e aspetuais. A nova interpolação, tal como a interpolação medieval e a interpolação de não, situa-se sempre à esquerda do verbo e depende da presença na frase de um proclisador diferente de não, sem implicar adjacência entre o proclisador e o clítico - cf. (41e/41j/41m) e (38d/38i), acima.

(41) a. Oi! Quando me ela disse aquilo! (CORDIAL-SIN, Corvo)

b. Mesmo dentro de uma marmita se eles governam (CORDIAL-SIN, Alte)

c. Tem de se pôr um garnel para se eles não forçar. (CORDIAL-SIN, Ponta Garça)

d. Também as eu ali tenho, que já dá para a minha vida (CORDIAL-SIN, Monsanto)

e. Vamos lá que eu the lá vou ensinar. (CORDIAL-SIN, Monsanto)

f. Eu a gilete ainda $a$ aí tenho (CORDIAL-SIN, Unhais da Serra)

g. Sei que $a$ aqui tenho por baixo, a maça de amaçar o linho (CORDIAL-SIN, Porto de Vacas)

h. Também se cá usa, mas agora não sei dizer qual é esta (CORDIAL-SIN, Figueiró)

i. Todos os dias se para lá ia achar túbara (CORDIAL_SIN, Lavre)

j. Ele veio lá a casa mas eu já o lá não tinha. (CORDIAL-SIN, Unhais da Serra)

1. Trigo é que se já semeou aqui muito mas agora é pouco (CORDIAL-SIN, Alcochete)

$\mathrm{m}$. aquele, o tal que eu vos já falei que tinha uns livros muito bons (CORDIAL-SIN, Covo)

(42) a. Tão bem arrecadado está, que não há meio de lhe eu pôr a vista. (João Araújo Correia, Terra Ingrata)

b. O que me eu parece é que nós temos cedo muita pancada rija (Almeida Garrett, Viagens na minha Terra)

c. Que queres mais que te ele dê? (Raul Brandão, Os Pobres)

d. Nunca duvidei do que me elas diziam (Almeida Garret, Viagens na minha Terra)

e. Não houve quem fosse indiferente ao sucesso, que o conselheiro narrou ainda sob a opressiva influência que lhe êle deixara (Júlio Dinis, A Morgadinha dos Canaviais)

f. E voto a Christo, que me parece o mesmo mancebo que vos aqui procurou há um ano... (Alexandre Herculano, O Monge de Cistér) 
g. A receber alguma paga há de ser de quem me cá mandou. (Camilo Castelo Branco, Amor de Perdição)

h. Quem me lá dera outra vez! (Camilo Castelo Branco, O Condenado)

i. Sorriu-se o morgado para dentro por que lhe já não ficava bem indignar-se por dentro nem por fôra. (Camilo Castelo Branco, A Queda d'um Anjo)

A julgar pelos exemplos em (42), no século XIX a interpolação de dêiticos não seria tida por fenómeno dialetal a excluir da língua literária. Posteriormente, tornou-se quase invisível na produção escrita, ainda que continue a ser possível atestá-lo em textos jornalísticos (e talvez uma investigação sistemática em textos literários venha a revelar que também aí não desapareceu - cf. Cunha/Cintra 1984, 314).

(43) a. Quem não hesita em fazer uma coisa daquelas não tem com certeza, em privado, princípios que nos possam tranquilizar. Como de resto, se já constatou. (Público, 25.03.2011, Vasco Pulido Valente)

b. Onde é que se já ouviu falar de semelhante esquema? (CETEMPúblico)

c. Os verdadeiros aristocratas apreciadores de pólo - os únicos que no domingo se mantiveram fiéis ao que os lá levara, assistindo à segunda partida - não vão habitualmente para as bancadas. (CETEMPúblico)

d. Segundo o director de São Francisco Xavier, a explicação de Joaquim Fernandes para o facto de os sacos terem aparecido na lixeira de Setúbal foi a de que «deve ter sido o motorista que os lá foi pôr sem autorização». (CETEMPúblico)

e. E no beijo de gratidão que the ele deu, bem viu ela que jamais a fome lhes bateria à porta. (CETEMPúblico)

\section{Conclusão}

Neste capítulo caracterizou-se o sistema de colocação dos pronomes clíticos no português europeu, pondo em destaque as suas especificidades, no quadro das línguas românicas, a sua complexidade, decorrente de depender da articulação entre fatores gramaticais diversos (sintáticos, lexicais, semânticos, pragmáticos, morfológicos), e o percurso diacrónico inusual e intrigante que se desenha entre o português das primeiras fontes escritas e o português contemporâneo, envolvendo variação, mudança e estabilidade. Apesar de o tema da colocação dos pronomes clíticos ter suscitado continuamente muito interesse e atenção (e ter originado uma extensíssima bibliografia que só em parte pôde ser referida neste capítulo), muitas questões permanecem ainda em aberto, são parte essencial do estado da arte e continuarão a alimentar a investigação neste domínio. 
Martins, Ana Maria (2016). A colocação dos pronomes clíticos em sincronia e diacronia. In: Ana Maria Martins \& Ernestina Carrilho (eds.), Manual de Linguística Portuguesa. Berlin/Boston: De Gruyter. 401-430.

\section{Referências}

Andrade, Aroldo (2010), A Subida de Clíticos em Português: Um estudo sobre a variedade europeia dos séculos XVI a XX, tese de Doutoramento, Campinas, SP, Instituto de Estudos da Linguagem, Universidade Estadual de Campinas.

Álvarez, Rosario/Xove, Xosé (2002), Gramática da Lingua Galega, Vigo, Galaxia.

Barbosa, Pilar (1996), Clitic Placement in European Portuguese and the Position of Subjects, in: Aaron Halpern/Arnold Zwicky (edd.), Approaching Second: Second Position Clitics and Related Phenomena, Stanford, California, CSLI, 1-40.

Barbosa, Pilar (2000), Clitics: A Window into the Null Subject Parameter, in: João Costa (ed.), Portuguese Syntax: New Comparative Studies, Oxford/New York, Oxford University Press, 31-93.

Batllori, Montserrat/Iglésias, Narcís/Martins, Ana Maria (2005), Sintaxi dels clítics pronominals en català medieval, Caplletra 38, 137-177.

Bouzouita, Miriam (2008a), The Diachronic Development of Spanish Clitic Placement, tese de Doutoramento, London, King's College London.

Bouzouita, Miriam (2008b), At the Syntax-Pragmatics Interface: Clitics in the History of Spanish, in: Robin Cooper/Ruth Kempson (edd.), Language in Flux: Dialogue Coordination, Language Variation, Change and Evolution, London, King's College Publications, 221-263.

Cardoso Pires, José $\left({ }^{4} 1975,{ }^{1} 1963\right)$, Jogos de Azar, Lisboa, Moraes.

Castillo Lluch, Mónica (1996), La Posición del Pronombre Átono en la Prosa Hispánica Medieval, tese de Doutoramento, Paris, Université Paris XIII.

Castro, Ivo (2002), Sur le bilinguisme littéraire castillan-portugais, in: Luísa Bras de Oliveira (ed.), La littérature d'auteurs portugais en langue castillane, Lisboa/Paris, Fundação Calouste Gulbenkian, 11-23.

Catalán, Diego (ed.) (1977), Gran Crónica de Afonso XI, vol. 2, Madrid, Cátedra Seminario Ménéndez Pidal/Gredos.

CETEMPúblico - Corpus de Extratos de Textos Electrónicos MCT/Público, http://www.linguateca.pt/CETEMPublico/ (13.05.2016).

Chenery, Winthrop Holt (1905), Object Pronouns in Dependent Clauses: A Study in Old Spanish Word Order, Publications of the Modern Language Association of America 20, 1151.

Cintra, Luís Filipe Lindley (ed.) (1990), Crónica Geral de Espanha de 1344, Edição crítica do texto português, vol. 4, Lisboa, Academia Portuguesa de História.

CLUL (ed.) (2014), P.S. Post Scriptum, Arquivo Digital de Escrita Quotidiana em Portugal e Espanha na Época Moderna [2016], http://ps.clul.ul.pt (13.05.2016).

CORDIAL-SIN - Syntax-oriented Corpus of Portuguese Dialects, http://www.clul.ul.pt (13.05.2016).

Costa, João/Fiéis, Alexandra/Lobo, Maria (2014), Input variability and late acquisition: clitic misplacement in European Portuguese, Lingua 161, 10-26.

Costa, Maria João (2001), Contributos para o estudo das perífrases verbais com «aver»e «teer» no português medieval, in: Clara Nunes Correia/Anabela Gonçalves (edd.), Actas do XVI Encontro da Associação Portuguesa de Linguística, Lisboa, Associação Portuguesa de Linguística, 179-186.

Cunha, Celso/Cintra, Luís Filipe Lindley (1984), Nova Gramática do Português Contemporâneo, Lisboa, Edições João Sá da Costa.

Döhla, Hans-Jörg (2014), Diachronic convergence and divergence in differential object marking between Spanish and Portuguese, in: Kurt Braunmüller/Steffen Höder/Karoline Kühl (edd.), Stability and Divergence in Language Contact. Factors and Mechanisms, Amsterdam/Philadelphia, Benjamins, 265-289.

Domingos, Manuel (2010), A colocação dos pronomes clíticos no português (oral) de Angola (POA), Trabalho do seminário de Linguística Comparada: Tópicos de Gramática do 
Martins, Ana Maria (2016). A colocação dos pronomes clíticos em sincronia e diacronia. In: Ana Maria Martins \& Ernestina Carrilho (eds.), Manual de Linguística Portuguesa. Berlin/Boston: De Gruyter. 401-430.

Português numa perspetiva comparativa, Lisboa, Faculdade de Letras da Universidade de Lisboa.

Duarte, Luiz Fagundes (ed.) (1986), Os Documentos em Português da Chancelaria de D. Afonso III (Edição), dissertação de Mestrado, Lisboa, Faculdade de Letras da Universidade de Lisboa.

Duarte, Inês/Matos, Gabriela (2000), Romance Clitics and the Minimalist Program, in: João Costa (ed.), Portuguese Syntax: New Comparative Studies, Oxford/New York, Oxford University Press, 116-142.

Duarte, Inês (2003), Padrões de colocação dos pronomes clíticos, in Maria Helena Mira Mateus et al., Gramática da Língua Portuguesa, Lisboa, Caminho, 847-867.

Fernández-Rubiera, Francisco J. (2006), Clitic Placement in Asturian: Evidence for a Syntactic FocusP Interaction, Georgetown University Working Papers in Linguistics 2006, 89-126.

Fernández-Rubiera, Francisco J. (2009), Clitics at the Edge: Clitic Placement in Western Iberian Languages, tese de Doutoramento, Washington, D.C., Georgetown University.

Fernández-Rubiera, Francisco J. (2010), Force ${ }^{o}$, Finiteness ${ }^{o}$ and the placement of clitics in Western Iberian Romance languages, Estudos de Lingüística Galega 2, 75-95.

Ferrando, Antoni (ed.) (2007), Curial e Güelfa, Toulouse, Anacharsis.

Fiéis, Alexandra (1996), Clíticos num Corpus do Português do Século XIII, dissertação de Mestrado, Lisboa, Faculdade de Ciências Sociais e Humanas, Universidade Nova de Lisboa.

Fischer, Susan (2002), The Catalan Clitic System: A Diachronic Perspective on its Syntax and Phonology, Berlin, Mouton de Gruyter.

Fodor, Janet Dean/Ivan A. Sag (1982), Referential and Quantificational Indefinites, Linguistics and Philosophy 5, 355-398.

Galves, Charlotte/Britto, Helena Britto/Sousa, Maria Clara Paixão de (2005), The change in clitic placement from Classical to Modern European Portuguese: Results from the Tycho Brahe Corpus, Journal of Portuguese Linguistics 4, 39-67.

Galves, Charlotte/Sousa, Maria Clara Paixão de (2005), Clitic placement and the position of subjects in the history of European Portuguese, in: Twan Geerts/Ivo van Ginneken/Haike Jacobs (edd.), Romance Languages and Linguistic Theory 2003: Selected Papers from «Going Romance», Amsterdam/Philadelphia, Benjamins, 97-113.

Gillier, Raïssa (2009), A colocação dos pronomes pessoais clíticos em Jorge de Sena e José Cardoso Pires - variação idiolectal, Trabalho do seminário de Linguística Comparada: Tópicos de Gramática do Português numa perspetiva comparativa, Lisboa, Faculdade de Letras da Universidade de Lisboa.

Gonçalves, Rita (2009), A colocação dos pronomes clíticos no português oral de São Tomé: Análise e discussão de contextos numa perspectiva comparativa, Trabalho do seminário de Linguística Comparada: Tópicos de Gramática do Português numa perspetiva comparativa, Lisboa, Faculdade de Letras da Universidade de Lisboa.

González i Planas, Francesc (2007), Sintaxis de los clíticos pronominales en asturleonés, Ianua Revista Philologica Romanica 7, 15-35.

Granberg, Robert Arthur (1988), Object Pronoun Position in Medieval and Early Modern Spanish, tese de Doutoramento, Los Angeles, University of California at Los Angeles.

Harris, James/Halle, Morris (2005), Unexpected Olural Inflections in Spanish: Reduplication and Metathesis, Linguistic Inquiry 36, 195-222.

Higginbotham, James (1987), Indefiniteness and Predication, in: Eric J. Reuland/Alice G. ter Meulen (edd.), The Representation of (In)definiteness, Cambridge, MA, MIT Press.

Hinzelin, Marc-Olivier (2010), L'interpolation dans les langues romanes: aspects diachroniques, in Maria Iliescu/Heidi Siller Runggaldier/Paul Danler (edd.), Actes du XXV Congrès International de Linguistique Romane, Innsbruck 2007, vol. 2, Berlin, Mouton De Gruyter, 331-340.

Justino, Víctor Mércia (2010), Estudo Comparativo dos Padrões de Colocação dos Pronomes Clíticos nos Discurso s Oral e Escrito do Português de Moçambique, Trabalho do 
Martins, Ana Maria (2016). A colocação dos pronomes clíticos em sincronia e diacronia. In: Ana Maria Martins \& Ernestina Carrilho (eds.), Manual de Linguística Portuguesa. Berlin/Boston: De Gruyter. 401-430.

seminário de Linguística Comparada: O Português em África, Lisboa, Faculdade de Letras da Universidade de Lisboa.

Kaiser, George (1992), Zur Grammatik der klitischen Personalpronomina im Französischen und Portugiesischen: Eine synchronische und diachronische Analyse im Rahmen der Prinzipien- und Parametertheorie, tese de Doutoramento, Hamburg, Universität Hamburg.

Kato, Mary/Martins, Ana Maria (2016), European Portuguese and Brazilian Portuguese: An overview on word order, in: Leo Wetzels/Sergio Menuzzi/João Costa (edd.), The Handbook of Portuguese Linguistics, Hoboken, NJ, Wiley/Blackwell, 15-40.

Lawton, Robert A. (1966), La syntaxe des pronoms personnels atones en ancien portugais: la phrase principale à sujet initial, et à verbe initial, in: Actas do V Colóquio Internacional de Estudos Luso-Brasileiros, vol. 3, Coimbra, 5-17.

Luís, Ana R./Kaiser, George (2016), Clitic Pronouns: Phonology, Morphology and Syntax, in: Leo Wetzels/Sergio Menuzzi/João Costa (edd.), The Handbook of Portuguese Linguistics, Hoboken, NJ, Wiley/Blackwell, 210-233.

Macchi, Giuliano (ed.) (1975), Fernão Lopes, Crónica de D. Fernando, Edição crítica, Lisboa, Imprensa Nacional, Casa da Moeda.

Madeira, Ana Maria (1993), Clitic-second in European Portuguese, Probus 5, 155-174.

Madeira, Ana Maria/Xavier, Maria Francisca (2009), The Acquisition of Clitic Pronouns in L2 European Portuguese, in: Acrísio Pires/Jason Rothman (edd.), Minimalist Inquiries into Child and Adult Language Acquisition: Case Studies across Portuguese, Berlin/New York, Mouton de Gruyter, 273-299.

Magro, Catarina (2005), Introdutores de orações infinitivas - o que diz a sintaxe dos clíticos, in: Inês Duarte/Isabel Leiria (edd.), Actas do XX Encontro Nacional da Associação Portuguesa de Linguística, Lisboa 2004, Lisboa, Associação Portuguesa de Linguística, 649-664, http://repositorio.ul.pt/handle/10451/6083 (13.05.2016).

Magro, Catarina (2006), Clíticos: Variação sobre o Tema, tese de Doutoramento, Lisboa, Faculdade de Letras da Universidade de Lisboa.

Magro, Catarina (2010a), Interpolação \& Cia. Nos dialectos do Português Europeu, Estudos de Lingüística Galega 2, 97-119.

Magro, Catarina (2010b), When corpus analysis refutes common beliefs: The case of interpolation in European Portuguese dialects, Corpus 9, 115-135.

Mapasse, Ermelinda Lúcia Atanasio (2005), Clíticos Pronominais em Português de Moçambique, dissertação de Mestrado, Lisboa, Faculdade de Letras da Universidade de Lisboa.

Marquilhas, Rita (2000), A Faculdade das Letras: Leitura e wscrita em Portugal no séc. XVII, Lisboa, Imprensa Nacional - Casa da Moeda.

Martins, Ana Maria (1994), Cíticos na História do Português, tese de Doutoramento, Lisboa, Faculdade de Letras da Universidade de Lisboa.

Martins, Ana Maria (1997), Alguns, muitos, poucos, todos e a relação sintaxe-semântica, in: Ana Maria Brito et al. (edd.), Sentido que a Vida Faz: Estudos para Óscar Lopes, Porto, Campo das Letras, 679-692.

Martins, Ana Maria (2001), Documentos Portugueses do Noroeste e da Região de Lisboa: Da produção Primitiva ao Século XVI, Lisboa, Imprensa Nacional - Casa da Moeda.

Martins, Ana Maria (2006), Aspects of infinitival constructions in the history of Portuguese, in: Randall S. Gess/Deborah Arteaga (edd.), Historical Romance Linguistics: Retrospective and perspectives, Amsterdam/Philadelphia, Benjamins, 327-355.

Martins, Ana Maria (2011), Clíticos na história do português à luz do teatro vicentino, Estudos de Lingüística Galega 3, 83-109.

Martins, Ana Maria (2013), A colocação dos pronomes pessoais clíticos, in: Eduardo B. Paiva Raposo et al. (edd.), Gramática do Português, vol. 2, cap. 42, Lisboa, Fundação Calouste Gulbenkian, 2231-2302.

Martins, Ana Maria (2015), Variação sintática no português quinhentista: a colocação dos pronomes clíticos, Estudos de Lingüística Galega 7, 83-94. 
Martins, Ana Maria (2016). A colocação dos pronomes clíticos em sincronia e diacronia. In: Ana Maria Martins \& Ernestina Carrilho (eds.), Manual de Linguística Portuguesa. Berlin/Boston: De Gruyter. 401-430.

Miranda, Sílvia (2013), Reconstituição do ms. L da Crónica Geral de Espanha de 1344 (2. ${ }^{a}$ Parte), Relatório final de estágio de mestrado, Lisboa, Faculdade de Letras da Universidade de Lisboa, http://repositorio.ul.pt/handle/10451/9403 (13.05.2016).

Moraes, Maria Aparecida Torres (1995), Do Português Clássico ao Português Moderno: Um estudo da cliticização e do movimento do verbo, tese de Doutoramento, Campinas, SP, Instituto de Estudos da Linguagem, Universidade Estadual de Campinas.

Namiuti, Cristiane (2006), Um Estudo sobre o Fenômeno da Interpolação na História do Português, Cadernos de Estudos Lingüísticos 48, 171-194.

Namiuti, Cristiane (2008), Aspectos da História Gramatical do Português. Interpolação, Negação e Mudança, tese de Doutoramento, Campinas, SP, Instituto de Estudos da Linguagem, Universidade Estadual de Campinas.

Nieuwenhuijsen, Dorine (2006), Cambios en la colocación de los pronombres átonos, in: Concepción Company Company (ed.), Sintaxis Histórica del Español, México, Universidad Nacional Autónoma de México, Fondo de Cultura Económica, 1337-1404.

Ogando, Victoria (1980), A colocación do pronome átono en relación co verbo no galegoportugués medieval, Verba 7, 251-282.

Oltra-Massuet, Isabel/Karlos Arregi (2005), Stress-by-Structure in Spanish, Linguistic Inquiry $36,43-84$.

Paiva, Conceição/Barbosa, Pilar (submetido), Clitic climbing in the speech of Braga and Lisbon, in: Pilar Barbosa/Conceição Paiva/Celeste Rodrigues (edd.), Studies on Variation in varieties of Portuguese, Amsterdam/Philadelphia, Benjamins.

Pato, Raymundo A. Bulhão (ed.) (1884), Cartas de Afonso de Albuquerque seguidas de Documentos que as Elucidam, vol. 1, Lisboa, Academia Real das Sciencias de Lisboa.

Piel, Joseph M./Mattoso, José (edd.) (1980), Livros Velhos de Linhagens, Lisboa, Academia das Ciências de Lisboa.

Potsma, Gertjan (2010), The impact $f$ failed changes, in: Anne Breitbarth et al. (edd.), Continuity and Change in Grammar, Amsterdam/Philadelphia, Benjamins, 269-302.

Ramsden, Herbert (1963), Weak-Pronoun Position in the Early Romance Languages, Manchester, Manchester University Press.

Ribeiro, Ilza (1995), A sintaxe da ordem no português arcaico: o efeito V2, tese de Doutoramento, Campinas, SP, Instituto de Estudos da Linguagem, Universidade Estadual de Campinas.

Roberts, Ian (1992), A formal account of grammaticalization in the history of Romance futures, Folia Linguistica Historica 13, 219-258.

Roberts, Ian/Roussou, Anna (2002), The History of the Future, in: David W. Lightfoot (ed.), Syntactic Effects of Morphological Change, Oxford/New York, Oxford University Press, 23-56.

Roberts, Ian/Roussou, Anna (2003), Syntactic Change: A Minimalist Approach to Grammaticalization, Cambridge, Cambridge University Press.

Rocha, Nilzete (2009), Clíticos: Ingrediente na Cozinha Portuguesa do século XVII, dissertação de Mestrado, Salvador, Bahia, Universidade Federal da Bahia.

Salvi, Giampolo (1990), La sopravvivenza della legge di Wackernagel nei dialetti occidental della Peninsola Iberica, Medioevo Romanzo 15, 117-210.

Silva, Rosa Virgínia Mattos e (1989), Estruturas Trecentistas: Elementos para uma Gramática do Português Arcaico, [Lisboa,] Imprensa Nacional - Casa da Moeda.

Sousa, Maria Clara Paixão de (2004), Língua Barroca: Sintaxe e História do Português de 1600, tese de Doutoramento, Campinas, SP, Instituto de Estudos da Linguagem, Universidade Estadual de Campinas.

WOChWEL's POS-tagged and Parsed Old Portuguese Texts (Ana Maria Martins, coord., CLUL/FCT), http://alfclul.clul.ul.pt/wochwel/oldtexts.html (13.05.2016).

ANA MARIA MARTINS 